\title{
The Promise of Planning: Technocracy and Populism in the Making of Peronist Argentina
}

\author{
EDUARDO ELENA \\ State University of New York, Stony Brook
}

\begin{abstract}
Los timoratos, los pobres de espíritu y los mediocres prefieren siempre los pequeños proyectos. Las naciones grandes, como la nuestra, con grandes aspiraciones e ilusiones, deben tener también grandes planes. Nada grande puede hacerse proyectando pequeñeces, y por eso nuestro plan concreta una gran ilusión que acariciamos los argentinos. ${ }^{1}$
\end{abstract}

During his time in office (1946-1955), Argentine president Juan D. Perón extolled the virtues of comprehensive state planning -entrusted to technical experts in federal bureaucracies and guided by himself, the Conductor-as a tool for social and economic modernization. Perón was, of course, not alone in envisioning national progress in these terms, as countless political regimes experimented with state planning throughout the twentieth century. Faced with the crisis of World War I, European states mobilized their populations and economic producers as never before. In the war's aftermath, Soviet officials endeavored to create a socialist civilization by applying state planning on an ever-grander scale, beginning with the New Economic Policy (1921) and First Five Year Plan (1928). From these origins as a wartime and revolutionary measure, state planning evolved into an accepted feature of modern statecraft. The ideal of technical coordination by national government was integral to attempts at steering a third-way between the extremes of Soviet socialism and laissez-faire liberalism, as exemplified by European fascism. Likewise, the developmentalist ideologies of the post-World War II era emphasized the application of social scientific expertise and centralized organization by the state in the "Third-World."

1 Perón (1985: 8, 222), noviembre de 1946. 
Scholars are in the process of reevaluating the significance of state planning as a major facet of twentieth-century world history. Studies have focused on the types of social knowledge that provided state officials with new techniques for governance and sources of authority. Rather than seeing planning as a path to national liberation, most recent works have stressed the authoritarianism of technocratic rule, which worked at cross-purposes with democratic politics and facilitated the forced relocation of populations, genocides, and state terror that marked the past century. ${ }^{2}$ Within the field of Argentine history, the state has become a topic for greater scholarly attention in its own right, motivated partly by a desire to understand the evolution of bureaucratic power in the twentieth century. Thanks to studies by Patricia Berrotarán and others, we now have a more complete account of the intellectual origins and institutional precursors to Perón's own Five-Year Plans. ${ }^{3}$ Authors have traced the history of individual government agencies (especially during the 1946-1955 Peronist administrations), as well as the negotiations between state planners, business elites, and military officials, among others. ${ }^{4}$

This essay considers the political history of planning in Argentina as a way of understanding the origins of Peronism in a new light. In particular, it challenges the tendency of recent studies to equate state planning too narrowly with technocracy, that is, with an impulse among highly-trained government officials to assert their autonomy and remove themselves from the political process. Indeed, historians have gone to the extreme of viewing planning in opposition to politics (what James Ferguson's study of developmental policies termed the "anti-politics machine"); or at best, they consider it a restrictive political paradigm imposed from above by state officials on unwilling subjects. To be sure, this technocratic impulse is a common feature of twentiethcentury states. But the history of planning in Argentina (as elsewhere) should not be limited only to the analysis of government institutions and experts, as important as these subjects are. This essay will investigate the broader political dimensions of planning in Argentina during the critical historical conjuncture of the Second World War and its aftermath. As we shall see, state planning was a subject that attracted intense debate and political coalition building among non-governmental actors, including social scientists, labor unions, and

2 The most far-ranging analysis of "high-modernist" planning is provided by: Scott (1998). Other key works in this vein include Ferguson (1994); Holston (1989); Prakash (1999); Rabinow (1989); Robertson (1984).

3 Berrotarán (2004); Berrotarán and Villarruel (1995).

4 Recent works on the authoritarianism of the Argentine state include, Pucciarelli (ed.) (2004). For studies of the Peronist state, see Ballent (1993); Ross (1993); Gaggero / Garro (1996); Novick (1986). 
business organizations. Moreover, planning occupied a prominent role in populist politics during the justicalista era and figured in Peronist strategies to court a mass political following.

A particular combination of international and domestic factors came to bear during the early 1940s that contributed to the fervor over state planning in Argentina. The eruption of the Second World War in September 1939 raised fears that Argentina would fall prey to yet another international economic crisis, either during the war itself or in the transition to an unknown postwar order. This anxiety was coupled with optimism among sectors that wished to alter Argentina's liberal order and a growing willingness to consider state intervention in socio-economic reform on a national scale. Postwar planning encompassed a wide range of opinions on different policy issues: industrial protection, social insurance, public works, scientific research, labor legislation, energy and natural resource development, technical education, and national defense, to name but a few.

Given this diversity of motivations, it is not surprising that state planning was conceived of in multiple, often clashing, ways during this wartime conjuncture. By exploring the shifting boundaries of "planning" as a subject of public contention, this essay situates the rise of Perón's political movement within the context of pre-existing debates over reforming the Argentine state. At its core, state planning represented a paradigm of modern governance, in which social scientific knowledge and techniques would be used to rationalize state institutions. Its advocates were concerned primarily with augmenting the power of the central state to regulate economic activity and to manage the social needs of the population. ${ }^{5}$ While many warned against "excessive" state intervention, planning discussions contained an implicit critique of Argentine liberalism's agro-export economy and limited state social programs. Yet many of those involved in these wartime debates also envisioned planning more broadly as a process of coordinating interactions between state and non-state authorities; in this view, government officials would create institutional channels to tap the expertise of professionals (engineers, economists, architects, etc.) and representatives of major economic interests (industrialists, agricultural producers, etc.) in formulating policies. For some, this coordinating func-

5 This broad definition of planning calls to mind Michel Foucault's notion of "governmentality," which he used to describe the state's assumption of a whole set of managerial duties and forms of knowledge. Foucault suggests that the role of the central state has become increasingly to ensure the full, efficient exploitation of national resources, including the maintenance of a healthy and productive population. Burchell (1991: 87104). For the intertwined histories of social science and state planning, see Rueschemeyer / Skopol (eds.) (1996). 
tion of planning meant creating corporatist structures modeled on fascist European regimes. As this essay will suggest, the politics of planning in Argentina were marked by this tension between the exclusivity of technocracy and the desire for greater coordination among social forces.

In addition to examining these wartime negotiations over postwar planning, the essay sheds light on one of the institutional and discursive foundations upon which Peronist mass politics was built. Perón and his advisors made great efforts to convince supporters of the power of central state planning. The Peronist regime followed in the paths blazed by the propaganda-makers of fascist Europe, as well as foreshadowing the mass mobilizations of other Third World planning states. As this essay will suggest, the Peronist vision of a "New Argentina" was based, in part, on an appeal to the authority of technical elites to manage socio-economic forces. Much of the scholarship on Peronism -and more generally, on populism in Latin America- has tended to downplay the influence of "scientific" discourses in favor of other factors. Perhaps this lack of scholarly attention can be attributed in part to the ascendancy in recent decades of a neo-liberal variant of technocracy across Latin America, which seeks to shield policymaking authority from popular politics. But as the case of Peronism in the 1940s makes clear, the cult of the populist leader and the technique of planning could also exist in complementary fashion to one another, although not without friction. ${ }^{6}$

This essay explores how Perón and his advisors reworked policies, organizational structures, and reformist discourses to develop a distinctly Peronist version of planning. It begins with a look at the origins of "postwar planning" as a topic for public discussion during the war years. The second section considers the way that Perón both forged alliances and alienated members of this loose community of postwar experts, and the third offers an overview of the role of planning in mass politics during Perón's presidency. My objective is not to trace the institutional history of planning organizations, analyze the policies of Perón's regime, or investigate how popular sector Argentines interacted with the planning state, all important subjects treated by other studies. Rather, this work examines planning for insights into the emergence of new state practices and political discourses in postwar Argentina. By drawing comparisons with other cases, including European fascist regimes, the essay places

6 In more recent times, politicians such as Salinas de Gortari in Mexico have combined a neo-liberal variant of technocratic planning with a so-called "neo-populist" appeal. It would be worth exploring how the decade of Menemista rule in Argentina represented a similar hybridization. For historical and contemporary perspectives on Latin American technocracy, see Knight (1998, 223-48). Centeno / Silva (eds.) (1998); Dornbusch / Edwards (1991); Pucciarelli (ed.) (2004). 
the Argentine experience within global historical trends, while illuminating the particularities of how Perón and his counterparts addressed the promise of planning.

\section{Envisioning the Postwar}

Across the Atlantic World, the Second World War catalyzed the expansion of the structure and scope of central government. Among the belligerent powers, the demands of mobilizing populations for war intensified the state's coordination of national production and other key macro-economic concerns, as well as generating expectations of postwar social reform. Almost from the war's very start, groups within Argentina began to consider how central government could not just reduce temporary economic disturbances, but also pursue more ambitious strategies for national progress in the transition from war to peace. This period witnessed the rise of coalitions that were brought together for the first time under the umbrella of postwar planning. Although in the end these tentative alliances collapsed or were swept aside by the Peronist movement, early reform advocates played a crucial role in setting the parameters of postwar planning -in the process, creating precedents that were seized upon by subsequent political actors.

Postwar planning drew upon vibrant social and economic policy debates from the 1920s and 1930s. Individuals who participated in Argentine reformist circles came from diverse professional backgrounds and included social scientists, religious authorities, journalists, politicians, and labor activists, among others. These actors clustered into numerous intellectual communities, often centered on respective policy journals, political parties, or organizations (such as the Museo Social Argentino). ${ }^{7}$ For all their ideological differences, many of this period's prominent figures -Alejandro Bunge, Juan Cafferata, and Enrique Dickmann, for example- reached the common conclusion that the state was responsible for addressing the shortcomings of laissez-faire liberalism, above all, the risks faced by workers from illness, substandard housing, and unemployment in an unequal society. ${ }^{8}$ In addition, a newly trained generation of

7 Key journals included the Revista de Economía Argentina, Revista de Ciencias Económicas, and the Boletín del Museo Social Argentino. Political organizations such as the Partido Socialista also acted as key sources of communication and helped forge contacts between intellectuals, social scientists, and activists.

8 The issues raised by reformers remained within the basic parameters of the "social question" from earlier in the century; the moralistic language employed by turn-of-the-century "hygienists" had not completely disappeared, and some commentators continued to 
social scientists drew attention to macro-economic problems, above all, to the balance between industrialization and the traditional agro-export economy. In developing their thoughts about the national state's role, Argentine reform groups paid close attention to experiments with planning and social politics occurring elsewhere in the Atlantic World. Following patterns established during the heyday of nineteenth-century liberalism, the traffic of ideas flowed mostly one way, from "cutting-edge" progressives in Europe or the United States to their Latin American counterparts; information about the latest social and economic policy innovations arrived to southern shores in the 1920s and 1930s, helped along by correspondence with foreign experts and international conferences. This openness to international influences did not mean that Argentines were simply mimicking foreign examples, and trans-Atlantic comparisons did not preclude careful observation of specific social conditions in Argentina. ${ }^{9}$

As they looked abroad for comparisons, Argentine reformers across the ideological spectrum encountered numerous examples of state planning in action. In Italy, planning was closely associated with the creation of corporatist structures to bring labor and business under the aegis of the state; the formation of Italian corporatism began prior to the worldwide depression, but intensified in the early 1930s with the expansion of the Ministry of Corporations and major corporatist legislation in 1934. Hitler's rise to power was accompanied by the growth of German state control over business and labor relations, motivated mainly by the regime's ideology of national coordination and militaristic expansionism. ${ }^{10}$ But not all versions of interwar planning were associated with authoritarian politics. In the United States, the New Deal offered a collection of social programs and Keynesian-inspired economic policies that provided another model of planning for progressives. The impact of the New Deal among liberals could be seen in Britain's own Beveridge Plan (1942), which promised more wide-ranging, progressive reforms to the social insurance system and other welfare programs. These moderate reforms to lib-

rail against social danger, criminality, and degeneracy. Zimmermann (1995); Suriano, (ed.) (2000); Panettieri (ed.) (2000).

9 For a path-breaking look at this traffic in ideas, see Rodgers (1998).

10 For the purposes of this essay, corporatism is defined in narrow institutional terms as structures for economic management implemented by European fascist regimes, in keeping with a corporal metaphor of hierarchical representation and critique of liberalrepublican politics. Paxton (2004); De Grand (2004: 47-62). Throughout mid-twentiethcentury Latin America, governments (including Perón's) sought to apply certain corporatist policies, but stopped short of creating formal institutions along fascist lines to coordinate between business and labor. The Brazilian Estado Novo represented perhaps the most comprehensive of these examples. Erickson (1977). 
eralism generated wide enthusiasm, but there was no shortage of observers in Argentina (including social scientists) attracted to the corporatist organization of business and labor. ${ }^{11}$

Despite the frustrations of many reform advocates at the slow pace of change in the 1930s, especially on the social front, the Argentine national government did expand its regulation of the macro-economy over the decade. The Uriburu and Justo administrations pursued fiscal policies to defend the liberal model of agro-export economics from the shocks of the Great Depression, including the creation of new institutions such as the Central Bank in 1935 and boards to assist large agricultural producers. This trend continued through the outbreak of the Second World War, as Argentina's liberals proposed measures to protect their nation from new disruptions in the world economy. The first major reply to fears of wartime instability came in November 1940, as President Ramón Castillo presented to Congress the Programa de reactivación de la economía nacional, better known as the Plan Pinedo after its author, Treasury Minister Federico Pinedo. The Plan Pinedo consisted mostly of financial reforms designed to assist agricultural producers, create a more vibrant credit market, and bolster the beef and grain export economy. To save the liberal orthodoxy of free trade and comparative advantage, the Plan Pinedo proposed a series of unorthodox measures that expanded the regulatory power of the central state, including a proposal for state assistance in housing construction. For all of its efforts to chart a moderate course of intervention, however, the Plan Pindeo was ultimately rejected by Congress. ${ }^{12}$

Yet the Plan Pinedo's demise served, paradoxically, to intensify discussions of state planning in Argentina. The frustration of Pinedo's project (and his subsequent resignation from office in 1941) created an opportunity for other actors with alternative social and economic agendas to debate the course of national progress and devise plans of their own. In the process, "planning" was detached from the immediate interests of government officials focused on setting wartime policy and became more broadly associated in the early 1940s with civil groups that explored the transition from war to peace. With their attention focused on the task of "preparing for the postwar," social scientists and business organizations occupied the terrain vacated by the federal government.

11 Fondness for corporatism could be seen in the writings of mainstream social scientists such as Alejandro Bunge and his circle. Bunge (1940).

12 Ministerio de la Hacienda (1940). As Juan José Llach has convincingly argued, this failure of this planning proposal resulted mainly from deep partisan conflicts over federal interventions in provincial governments and electoral corruption -and not intrinsic opposition towards Pinedo's economic strategies. Llach (1984: 515-57); Pereyra (1995); Cramer (1998: 519-550) 
In the aftermath of the Plan Pinedo's failure, the Unión Industrial Argenti$n a$ (UIA) took the lead in creating an organizational framework for postwar discussions. The UIA established the Instituto de Estudios y Conferencias Industriales in 1942 to serve as a forum to exchange information about pressing social and economic topics. The Instituto's executive council and contributors included social scientists, factory owners, and military officers (typically civil engineers and directors of military-run factories, such as Colonel Manuel N. Savio). In May 1943 the UIA formed another organization known as the Congreso Permanente Para Estudio de los Problemas de Post-guerra y de la Economia General del Pais, which soon thereafter became the Congreso Permanente de Fuerzas Productoras. This larger group included hundreds of members drawn from ranks similar to those at the Instituto, but also brought together representatives from powerful commercial and agricultural institutions such as the Sociedad Rural Argentina and Bolsa de Comercio. ${ }^{13}$

The Instituto and Congreso were advisory boards that sought to educate Argentines about both the dangers and the prospects of the postwar. Gatherings were open to the public and reached a broader audience through the publication of pamphlets and occasional radio broadcasts; judging by the level of the discussions, however, these efforts were aimed mainly at an educated public that included government officials, policymakers, and businesspeople. Aside from the few military officers, participants in the UIA's organizations came from outside the government, and as a result, these bodies had no authority to determine policy directly. Membership was restricted to professionals and experts in economic and social affairs interested in moderate changes to the status quo. Political and civil groups that might upset the delicate centrist balance -such as labor unions, leftist parties, and the extreme right-were specifically excluded. ${ }^{14}$ Nevertheless, postwar organizations opened new channels of communication among individuals from the disparate worlds of the academy, industry, and the military.

In addition to these organizations, the work of postwar preparation was carried out in a handful of specialized journals, in particular the Revista de Economía Argentina (REA). Alejandro Bunge, the founder of this monthly magazine, had published works since the 1920 s on the issues that now concerned would-be planners. His book Una nueva Argentina (1940) argued

13 Revista de Economía Argentina (REA) May 1943: 175-77; Oct. 1943: 416-17.

14 Torcuato S. Di Tella offers insights into his father's role in the Instituto and the tensions produced by including experts from various professional and ideological backgrounds. For the sake of some semblance of ideological balance, the rightist catholic economist Alejandro Bunge, for instance, was paired with his more left-leaning counterpart Ricardo Ortiz. Di Tella, Torcuato Di Tella (1993: 119-20 and 126-38). 
forcefully for state action in industrialization, social welfare programs, growth of domestic consumption, and more efficient economic management. Bunge continued to stress the virtues of these policy goals in the pages of his magazine, and he was joined by likeminded engineers and economists who shared his social Catholic ideology. The REA reprinted articles published on postwar problems in newspapers such as La Nación and reported faithfully on the activities of the UIA's organizations. Bunge himself participated in the Instituto committees as an expert on industrial policy. Like the Instituto, the REA acted as a clearinghouse for technical knowledge on socio-economic policy, while also serving as a vocal advocate for postwar planning in determining government priorities.

The REA and UIA organizations remained open to policy examples that reached Argentina from abroad. By far the most discussed foreign models for Argentine planning were Roosevelt's New Deal, the United States's National Resources Planning Board, and above all, Britain's celebrated Beveridge Report. (Mentioning the "Plan Beveridge" became de rigeur in policy discussions throughout the 1942-1946 period.) Most social scientists and other would-be planners considered Argentina to be confronting socio-economic problems common to "modern" nations. In an April 1944 article "Anteproyecto de plan economico argentino para la posguerra" published in the REA, engineer Francisco García Olano asserted that the age of laissez faire was over, as witnessed by the different planning measures taken by Russia, Germany, Japan, and the United States after the crash of 1930. Olano concluded that political leaders needed to come to terms with the demands of modern times:

Hoy en guerra y mañana en la paz, todos los países deberán planificar sus economías, para mantener la producción, o adaptarla a las nuevas necesidades; asegurar una justa distribución de los productos, aumentando el consumo y mejorando el standard de vida de las masas, evitando y eliminando la desocupación. ${ }^{15}$

The diverse experts who participated in the UIA's conferences and committees exchanged views, but failed to agree on coherent policy directions. The differences of opinion on the issue of state support for industry -the most debated issue in planning circles- are suggestive of the distances that separated them. For Bunge and his peers at the REA, the central state was considered a force for diversifying industry and boosting the cycle of domestic employment, production, and consumption. By contrast, military officers concentrated on the importance of developing heavy industry and mining to defend

$15 \quad$ REA April 1944: 102. 
national independence. Luis Colombo, the UIA president, looked to the state to protect existing Argentine industries in the turbulent transition from war to peace.

There were similar tensions concerning what actions the state should take to guarantee social peace in the postwar transition. Torcuato Di Tella became the leading voice within the UIA for moderate reforms to improve the living conditions of industrial workers. In 1939, he represented the UIA at an International Labor Conference in Geneva; on a 1943 trip to the United States, he gathered additional information about New Deal programs and postwar planning, eventually drafting his own proposals for a national social insurance program and a "family wage" subsidy scheme. ${ }^{16}$ Other participants in the UIA planning activities made similar declarations about the need to uplift and protect workingclass families, but the actual commitment to social policy was limited at best. Colombo peppered his speeches with references to the New Deal and Beveridge Report, and at an April 1943 conference he asserted that his organization wished to protect workers "desde la cuna hasta la tumba" from life's risks. ${ }^{17}$ Yet under Colombo's leadership, the UIA lobbied against Socialist-sponsored congressional proposals for a minimum wage and for expanded labor legislation. ${ }^{18}$ After years of opposition or indifference to these sorts of projects, the UIA's sudden embrace of social welfare seemed like a gesture intended to win support for the more pressing goal of industrial protection.

UIA postwar planning, then, was an uneasy marriage between different interest groups and sources of expertise. Qualms about wartime collapse coexisted with a sense of possibility, and this optimism manifested itself in numerous ways. Reform-minded social scientists saw the potential to create social insurance and other programs that would shelter the growing urban proletariat from economic forces. Industrialists and their supporters envisioned greater state protections for local manufacturing. Argentina's exposure to crises imported from foreign shores convinced anti-imperialist critics -among them members of the military- of the virtues of economic nationalism. Under the auspices of planning organizations, these agendas mingled and established a common ground for discussion. Participants expressed deep concerns over the nature of state intervention in the Argentine economy and society. For a minority of these observers, coordinated planning entailed the formation of corporatist institutions at odds with liberal parliamentary democracy. ${ }^{19}$ Yet the main concern for most UIA "planners" was politically pragmatic, namely that

\footnotetext{
16 Di Tella (1941); Di Tella (1993: 110-115); REA Jan. 1944: 5-10.

17 REA May 1943: 176.

18 La Vanguardia 27 Sept. 1942: 1.

19 Bernardo (1945: 47-52).
} 
those with business and social scientific expertise take the leading role in determining the future course of national development. Virtually all these advocates warned against excessive "intervencionismo" from the state in private sector affairs. "Planning" was seen as a process of coordination between the state, business, and other forces, rather than top-down state dirigisme.

For many of those involved, postwar planning discussions were a way to exert influence on policymaking, in essence to prevent a model of closed technocracy from emerging. Yet even the most conservative sectors involved in these debates acknowledged that the central state would ultimately ensure that postwar proposals would not be confined to the conference hall and policy journal alone. In the 1943-1946 period, however, controlling the aspirations of state officials would prove more difficult than Colombo, Di Tella and their peers could have imagined. Perón and his allies would make postwar planning an integral part of their model of statecraft and their brand of populist politics, thus hastening the isolation and eventual collapse of earlier planning experiments.

\section{Peronist Planning}

On the morning of June 4, 1943, a military coup planned by a secretive club of young officers and led by General Arturo Rawson overthrew President Castillo. Between June 1943 and June 1946, Argentine politics revolved around these military officials and their internal wrangling for control of power (Potash 1969: 182-200; Rouquié 1982). The leaders of the June Revolution saw themselves as the nation's stewards, the only force that could cleanse Argentina of its political ills and impose a new order based on respect for religion and the patria. At the same time, military officers promised to create a more rational system of governance that would end what they perceived as the corruption of traditional politics. Colonel Juan Perón emerged unexpectedly from within this military regime as a high-profile advocate for the application of technical expertise in the remaking of the central state. By the end of the 1943-1946 period, Perón had incorporated the discourse of postwar planning into his rapidly expanding political movement and oversaw the creation of government planning institutions. Perón's involvement had a polarizing effect: while he succeeded in incorporating social scientists, military officers, and industrialists within his coalition, this support was by no means complete, and he was drawn into open conflict with business organizations such as the UIA.

The June Revolution regime began by engaging in new types of state management, intensifying the trend established by Pinedo and others in the 1930s. These reforms included a reorganization of existing federal departments and the establishment of agencies, including the National Industrial Credit bank to 
aid domestic manufacturing and the Instituto Nacional de Prevención Social to rationalize the nation's limited retirement system. With their emphasis on issues such as industrialization, infrastructure, and social welfare, these institutions addressed concerns raised in the ongoing postwar planning debates. Notwithstanding these institutional reforms and the rhetorical attention given to the ideal of technical expertise, decision-making power within the regime was shaped by the constant internal struggle among the military conspirators.

From his headquarters at the National Labor Department, Perón worked to secure a place for himself within the military government and devise his own vision of a new state. Péron's path from a military conspirator in June 1943 to president three years later is, without a doubt, one of the most well-traveled roads in Argentine historiography. Yet scholars have only recently begun to explore the origins of the Peronist movement in relation to wartime debates over state intervention and planning (Berrotarán 2004; Berrotarán and Villarruel, 1995). The question facing historians is a basic one: how did this army officer with virtually no experience in government become by 1946 Argentina's most famed advocate for socio-economic reform and state planning? Traditional accounts have typically emphasized Perón's own dynamism, especially his ability to transform the moribund Labor Department into a center for political activism. While the impact of Perón on this agency seems clear, much less attention has been given to how this institution, its staff, and its sources of social knowledge framed Perón's outlook on the problem of postwar planning.

In the course of his "education" as a postwar planning advocate in the 1943-1946 period, Perón depended upon a series of intermediaries that acted as bridges between the political power of the military regime and different social actors, including those involved in ongoing policy debates. The most famed intermediaries were labor union leaders drawn into contact with the Labor Department (elevated under Perón to a Secretariat). Through negotiations with organized labor Perón refined his social agenda by incorporating longstanding union proposals for health and safety regulations, wage contracts, social assistance programs, and the like. Union officials such as Atilio Bramuglia and Angel Borlenghi, who would later hold posts in the justicialista administration, occupied important positions as interlocutors between unions and government agencies.

Likewise, the Labor Secretariat's staff served to connect Perón to forms of social knowledge that would prove crucial in designing technical strategies for governance. ${ }^{20}$ The central figure in these interactions was the Secretaria's chief

20 These additional federal agencies under the Secretaria's control included the Comisión de Desempleo, Tribunal de Rentas, Caja Nacional de Ahorro Postal, Comisión de Casas 
of statistics, José Miguel Figuerola y Tressols. In his native Spain, he had helped to draft a national labor code and served in the fascistic Primo de Rivera regime's labor ministry. After emigrating to Argentina in 1930, he established himself rapidly among social scientists, serving on the board of the Revista de Ciencias Sociales and the Instituto de Politica Social of the Universidad de Buenos Aires. In 1933 Figuerola was appointed to a post at the Departamento Nacional de Trabajo (DNT). He complemented his official work by writing pieces for a social policy journals (including Bunge's $R E A$ ) and publishing a book that expounded his own corporatist philosophy, which called for the institutional integration of government, labor, and business in Argentina. ${ }^{21}$

Figuerola proved an invaluable source of social scientific knowledge to Perón on a host of pressing policy issues. In addition to publishing his own works in policy journals, the DNT's Chief of Statistics had devoted much of the late 1930s and early 1940s to gathering extensive information on workingclass life. Under his guidance, the DNT carried out detailed surveys of the workplace, housing, and spending patterns of Buenos Aires workers. Many of Figuerola's studies focused on household consumption, plotting the changes over time in the budgets of the "typical" working family (a male unskilled industrial worker, wife, and two or three children). In the absence of regular censuses, these were the most sophisticated, and in some cases, the only social surveys performed in Argentina during this period. More importantly, these reports created Argentina's first statistical definitions of minimum need -in essence, a semi-official "nivel de vida." 22 The analyses of these budgets made it possible to assert with the rigor of statistical authority one conclusion: the average worker could not meet his household's minimum needs. Charts compared the condition of Argentine workers with their counterparts in Europe and the USA, allowing one to gauge just how much Argentina trailed "advanced" nations.

With Perón's appointment as head of the DNT, Figuerola's policy and statistical expertise was called upon to new ends. In a 1966 magazine interview, Figuerola described his first meeting with the colonel: "We began talking at six in the afternoon. He wanted to see my files, to look at socio-economic statistics and graphs of standard of living curves for the last 12 years. We exchanged ideas and drank many cups of coffee and smoked dozens of cigarettes." The

Baratas, the División de Trabajo Femenino, and others. For more on the DNT, see Little (1988); Soprano (2000).

21 Figuerola (1943); (1939: 83-87); Page (1983: 68-69).

22 The agency's reports, many with commentary from Figuerola include: Departamento Nacional del Trabajo (1940); (1942); (1943). Secretaría de Trabajo y Previsión (1945); (1946 a); (1946 b). 
meeting finally ended at 2 in the morning, with Perón taking home a stack of charts on the nutritional deficiencies of working-class families. ${ }^{23}$ Placing aside the question of the accuracy of this recollection, Figuerola's story sheds light on how his expertise helped shape Perón's perception of society and its problems. Figuerola's surveys and projects exemplified the types of social knowledge and technical authority deployed by military officials like Perón in their experiments with state planning. The notion that trained officials could, through careful observation and a rational organization of central government, transform society became a central tenet of the Peronist vision of modernization.

This model of planning would reach its greatest heights in the 1943-1946 period in a new institution created by the military regime, the Consejo Nacional de Posguerra. Established in June 1944, this government advisory board was entrusted with devising strategies for limiting the disruptive effects of the war and charting the nation's economic and social path in the transition to peace. Reflecting his growing prominence within the regime, Perón was appointed president of the Consejo, and Figuerola was named as its main "technical advisor." Like the UIA's Instituto, this agency included experts from various branches of government (including the military), social scientific community, and private industry. The Consejo was structured around a set of "subcomisiones técnicas" staffed mainly by military officers, civilian bureaucrats, and social scientists, above all those who contributed to the REA, such as Rafael García Mata, Emilio Llorens, and Carlos Moyano Llerena. A few prominent industrialists also participated in the Consejo's "Subcomision Informativa Patronal," including Torcuato Di Tella. ${ }^{24}$ With this mix of members, the Consejo represented an achievement for advocates of greater cooperation among state, business, and social science. In practice, however, this planning board soon replaced the UIA's organizations as the main institutional forum for developing postwar policy. Although businesspersons had a place on the Consejo, they now occupied a secondary position to officials like Perón and Figuerola within the military government. ${ }^{25}$

23 Journalist Hugo Gambini interviewed Figuerola for the magazine Primera Plana in July 1966. Gambini (1999: 115).

24 Aside from Di Tella, the other members of this subcommittee were: Antonio Bergeron, Esteban Carbone, Mauro Herlitzka, Alejandro Shaw, Ernesto Pueyrredón, Luis P. O'Farrel, Carlos Menéndez Behety, Guillermo Kraft, Eustaquio Méndez Delfino, Carlos Alfredo Tornquist, Roberto Fraser, and José Dodero. Of these representatives of Argentina's business elite, three had also occupied posts in the UIA's Congreso. There was also an analogous committee comprised of representatives from foreign business organizations. The level of regular participation of both these groups in the Consejo is unclear. Consejo Nacional de Posguerra (1945: 54); REA Oct 1943: 416-17.

25 Berrotarán offers a thorough examination of the Consejo, its evolution as an institution, and its impact on later Peronist planning organizations. Berrotarán (2004: 45-113). 
In 1945, the Consejo published a report titled Ordenamiento EconómicoSocial that offered a public overview of its recommendations. The main priorities for the postwar, the Consejo maintained, were to prevent the collapse of wartime industrialization and to ensure full employment for the workforce. In discussing the postwar transition, the report drew parallels with the economic slump, inflation, and unemployment that occurred after World War I. To avert this catastrophe, the Consejo highlighted the importance of protecting domestic manufacturing, both as a way to prevent unemployment and to spur future growth. It called for government intervention to create new industries, train the workforce in technical skills, and diversify production in rural areas devoted to monoculture. In contrast to the Plan Pinedo, export agriculture occupied a notably reduced role in this postwar economic model. Reflecting the influence of Perón's growing ties with organized labor, the Consejo's report differed most significantly from earlier postwar discussions in its emphasis on state social and economic management. The "primordial" goal of the state's "economic-social ordering," according to this document, was to "secure the satisfaction of all the needs of the country's inhabitants, without tolerance for the unjust concentration of resources in the hands of a few." In practical terms, this meant not only full employment, but also a comprehensive social security system. Citing the famous phrase of British progressives, the 1945 report claimed that the postwar government would protect Argentines" "desde la cuna hasta el sepulcro" against the risks of illness, injury, unemployment, and old age. While warning against excessive "statism," the Consejo maintained that the state had a duty to arbitrate labor conflicts and establish a more "humane" system than the "hard rules of supply and demand."26

Representatives from Argentina's business community lent initial support to the Consejo's talk of "socio-economic ordering," but by mid-1945 business organizations viewed Perón's strategies for postwar planning with increasing trepidation. ${ }^{27}$ Perón's call for greater state support of industry had sparked the interest of many UIA members, including a minority faction that supported a more thorough integration of the organization under the central state. A few of these industrialists, such as Miguel Miranda and Rolando Lagomarsino, would break off from the skeptical majority of their peers and eventually occupy cabinet posts in Perón's government. Nevertheless, the UIA's leadership joined ranks with the anti-Peronist block in the campaigns leading up to the 1946 elections. Not surprisingly, the UIA and other business sectors exerted dimin-

26 Consejo Nacional de Posguerra (1945: 39-41).

27 For state-business relations, see Brennan (1998); Birle (1997); Cúneo (1967); Lucchini (1990); Schvarzer (1991). 
ishing influence in the postwar planning board under Perón's command; the Instituto faded away by 1946, as did the participation of its members in organizations created by the June Revolution government. In the process, the Consejo Nacional de Posguerra increased its autonomy in formulating postwar policy, becoming less a forum for exchanging opinion than a tool for officials within the national government.

This strained relationship between Argentina's largest industrialist organization and Perón represents an extreme case of a political dynamic common to mid-twentieth-century planning experiences. In the case of Fascist Italy, for instance, corporatist planning entailed constant negotiation between conservative business sectors seeking to maintain control over the operation of their enterprises and fascist technocrats (above all, Minister of Corporations Giuseppi Bottai) who advocated more extensive state command over economic activity. Business-owners feared invasive state regulation and the potential for labor mobilization under fascist command. Most historical works on the subject conclude, however, that in the end the largest Italian industrial and commercial groups were able to adapt successfully to the era of national planning, relying on the fascists to break up labor unions while making the most of new corporate structures to create protective cartels. Mussolini's pragmatism as a political leader, shaped by his need to build alliances between fascists and conservatives, tilted the balance towards a preservation of the established bourgeoisie (Sarti 1971; Adler 1995; Maier 1988: 3-19 and 545-578; De Grand 2004: 47-56). In Germany, Brazil, and the United States, key business sectors were also able to reach tense, if for some quite profitable, accommodations with state planners, although not without some sacrifices of their autonomy (Barkai 1990: 243-249; Erickson 1977).

There are multiple explanations for the more open level of conflict between the UIA and Perón in the crucial 1946 conjuncture. The most important factor was, of course, Perón's increasingly strong alliance with organized labor. As numerous historical studies have noted, state support for unions contributed to Argentine business organizations' distrust and eventual opposition of Perón. Moreover, Perón's failed efforts to court business under the banner of postwar planning occurred at a moment of relative political weakness; although his popularity was on the rise, Perón's victory in the 1946 election was not a foregone conclusion. In the case of Italy, Mussolini attempted substantive corporatist reform only after he had built alliances with business organizations and once he had consolidated his own power. Perón was a relative latecomer to postwar planning discussions, and his ability to exert control over the Consejo Nacional de Posguerra may have alienated some of those involved in pre-existing debates over the postwar transition. Timing no doubt played a major role in Argentina. The shift toward greater state intervention in other cases occurred 
typically after a major economic shock. While Argentine business groups feared postwar disruptions, they were in a favorable position compared to their contemporaries in fascist Europe and the United States during the early 1930s.

As with their counterparts elsewhere in the Atlantic World, industrialists and other Argentine businesspersons were able to adapt eventually to new economic policies created by Perón's planners. Capitalists established new business organizations in the 1946-1955 period, such as the Confederación General Económica, that sought greater communication with the state. Yet the difficult relationship between organizations such as the UIA and the Peronist regime early on had a lasting influence on the Peronist model of state planning. In contrast to corporatist systems, state-business negotiations occurred largely outside formal institutions that allowed policy input from the private sector. ${ }^{28}$ Under Perón, Argentine businesspersons were unable to follow the example of their Italian peers in turning planning organizations into tools for creating cartels and clamping down on labor militancy. The lines of communication opened in the early 1940s among industrialists, social scientists, and military officers had become restricted by Perón's electoral triumph, and they only partially and slowly reopened during his presidency. Debates over postwar planning had been marked by a tension between an ideal of state technocracy and an ideal of coordination between the public and private sectors. Despite the tentative efforts of Perón and some capitalists to build more formal coordinating institutions, his regime's version of planning relied heavily on the autonomy of the central state -and above all, its executive branch- to determine the future of postwar Argentina.

\section{Planning and Populism}

Over the 1946-1955 period, the Peronist administration's First and Second Five-Year Plans became powerful emblems of the commitment to state planning on a national level. Perón held fast to the conviction that what Argentina needed was strong executive leadership unencumbered by public debate or vigorous parliamentary politics. As with other protagonists of the 1943 June Revolution, Perón's militaristic sense of nationalist duty and anti-imperialism found common ground with arguments in favor of forceful state intervention

28 The actual process of negotiation between business organizations, individual capitalists, and Perón's government in the 1946-1955 remains poorly understood. Forthcoming works by James Brennan and other historians should shed light on the operation of trade lobbies and vaguely corporatist institutions such as the Consejo Económico Nacional. 
to manage Argentina's resources. At a basic level, the concentration of decision-making authority in the executive and a small group of advisors represented a continuation of earlier political patterns in Argentina. ${ }^{29}$ Nevertheless, Perón's government expanded the power of central bureaucracies, extended the reach of the national government into the provinces, and implemented a vast, if somewhat disorganized, program of social and economic reforms aimed at creating a "New Argentina."

But state planning in the Peronist era was not simply a matter of new policies and institutions. "Planificación" was also a key element in the regime's brand of populist politics. Rather than remaining a topic for a small coterie of experts, planning became the subject of intense propaganda campaigns that further infused public life with the metaphors and imagery of state-led progress. Although an elitist when it came to exercising state power, Perón differed from his predecessors in his efforts to communicate this ideal of state planning to a wide audience. Perón and his assistants invoked repeatedly the scientific, rational virtues of planning to justify their actions. In the process, they blurred the lines that had traditionally separated matters of public policy, government institution building, and mass politics in Argentina. While the political discourse of planning does not alone explain the popular appeal of Perón as a leader or the power of his political movement, it did form an important part of the Peronist ideology of national progress and social justice. Planning thus had a profound impact in the sphere of mass politics.

Throughout his early political career, Perón drew on terminology used in postwar planning debates. In his hundreds of speeches, radio addresses, and published texts produced during the 1943-1946 period, Perón made the social scientific language of planning a more familiar feature of mainstream politics. For instance, at an assembly of commercial retail workers gathered in December 1944, Perón defined for his audience what he called the "English" term "línea de vida": "Este consiste," explained Perón, "en el equilibrio del sueldo o jornal con las necesidades mínimas de la subsistencia en condiciones dignas." ${ }^{30}$ The government's main responsibility, he contended, was to prevent the working population from being "sumergidos" below this line or minimum "standard de vida." By incorporating "foreign" concepts into his speeches, Perón defined social justice in the international language of social science.

29 Gary Wynia's work on the Argentine state suggests the underlying continuities in the mechanisms of policymaking over the postwar period. Without ignoring the differences between civilian and military regimes, it draws attention to the concentration of authority in the executive branch and in non-institutionalized channels for negotiation with forces such as labor and business organizations. Wynia (1978: 43-80). 
(That the "línea de vida" and "standard" were identified as English suggests his audiences' at least partial unfamiliarity with these terms.) In addition to explaining his new terminology, Perón offered a summary of the state's mission in the postwar:

Es elemental obligación del Estado moderno el propugnar por todos los medios la existencia de un "standard de vida" adecuado para todos los habitantes, el que estará en razón directa con la economía nacional y el trabajo individual y con una organización adecuada del país, que permita llegar a la más perfecta coordinación y el máximo equilibrio económico-social. ${ }^{31}$

Here, as in countless other descriptions, the language of planning -"standard de vida", "organización," "coordinación," "equilibrio"- seeped into Peronist descriptions of social justice and national progress. Echoing the pronouncements of the Consejo Nacional de Posguerra, he maintained in subsequent public addresses that the central government needed to exert a "una función rectora y reguladora" to guarantee harmony in the postwar transition. ${ }^{32}$ Perón reinforced these claims by telling audiences that foreign leaders in "cultured countries" already realized that the state needed to soften the clashes between labor and capital. ${ }^{33}$ From this perspective, class conflict was not a permanent condition, but could be resolved by rational government intervention. Perón used the metaphor of society as a motor with many sets of gears, in which the state should act as a mechanic: regulating the flow of national resources, restraining chaotic market forces, and ensuring an equitable distribution of material rewards among the social classes. ${ }^{34}$

It is important to note that Perón's descriptions of the science of state planning existed side-by-side with other appeals. Perón spoke in many accents at once: in the same speech, he incorporated the rhetoric of Catholic morality, union solidarity, leftist class struggle, and popular colloquialism, to name but a few. More to the point, Perón's pronouncements about the power of the state were juxtaposed with statements designed to convince audiences of his own personal authority; it was only through his guidance that state planning would deliver real improvements to the everyday lives of Argentina's population. The concrete social reforms supplied by the Peronist government and the alliances brokered with unions -topics treated at length by this period's labor historieslent his descriptions of a "New Argentina" added weight. In institutional and

\footnotetext{
31 Perón $(1985: 7,534-535)$

32 Perón $(1985: 7,123)$.

33 Perón $(1985: 7,519)$.

34 Perón $(1985: 7,132)$.
} 
policy terms, this first generation of Peronists grafted the Secretaria's social agenda onto the Consejo Nacional de Posguerra's projects. But unlike other postwar planners, Perón did not speak exclusively in the language of technical expertise. Often in the same speech, he switched from exalting the science of state planning with to descriptions of anti-bureaucratic and personalist government. He distinguished the Secretaría from typical government bureaucracies, with what he once called their impersonal "technical-administrative mechanisms." The Secretaria was instead "the true house of workers," a protective space where dedicated officials served the laboring man and woman with empathy. ${ }^{35}$ It was through this interplay between discursive appeals and material rewards that Perón crafted a new sense of the politically possible, grounded in the science of state planning and charisma of populist leadership.

The first Plan Quinquenal epitomizes this confluence of planning and populism. Presented to Congress in October 1946, the Plan was at one level a policy statement comparable to the Plan Pinedo or similar proposals from the 1930s and 1940s. Its original focus was setting industrial policy, and the Plan's main architect, José Figuerola, addressed the key concerns of the UIA's Instituto and the Consejo Nacional de Posguerra, such as the need to protect existing industries, ensure adequate supplies of energy and raw materials, and further industrialization across the nation. Over the first few months of Perón's presidency, additional projects were added to the Plan Quinquenal before its presentation to Congress in October 1946, and the Plan covered issues ranging from public health and education to transportation and a restructuring of the state. Modern government, as Perón explained in his congressional speech introducing the Plan, required an orderly division of tasks: "el estadígrafo va a exponer la situación, el estadista dará los objetivos y el técnico ha de indicar el camino para alcanzarlos." ${ }^{36}$ As with his predecessors, Perón stressed the importance of social scientific knowledge to gain an objective picture of national economic problems and social conditions. In 1947, the federal government carried out a new national census -the first in nearly thirty-five yearsto gather the necessary statistical information with which to guide planning. A new agency, the Secretaria de Asuntos Técnicos, was created to oversee the Plan and to coordinate among the various branches of federal government, with José Figuerola as its first director. ${ }^{37}$

35 Perón (1985: 7, 231-232).

36 Presidencia de la Nación (1947: 187).

37 Behind the scenes, the practical realities of the Peronist planning state did not match the rhetoric of modern efficiency. Despite the formation of the Secretaria de Asuntos Técni$\cos$, there was an overall lack of coordination among various ministries in the immediate postwar. Overlapping and often redundant social assistance programs, for instance, 
Policy experts -including those who had participated in postwar debatesgreeted the Plan Quinquenal with mixed opinions. The contributors to the Revista de Economía Argentina supported the Plan Quinquenal and claimed that Perón's speeches echoed earlier reform discussions: "muchos de los conceptos enunciados coinciden substancialmente con la predica constante del ilustre inspirador de esta revista, Prof. Alejandro Bunge y que han seguido sus discípulos". They felt that despite some lack of specificity, the Plan provided a good roadmap for government action that could be improved "a la marcha." 38 Other social scientists responded more critically, either by noting the incompleteness of Peronist planning or attacking its excessive state interventionism. The Revista de Ciencias Económicas published articles between 1946 and 1949 that focused on the government's surge in public spending and heavyhanded economic interventions. José Gonzalez Galé, one of Argentina's leading experts on social insurance programs, pointed out that the regime's "caja de jubilación" system was financially unsound and unfairly burdened employers; in his opinion, the Peronist state's frenzied expansion of social programs would create new problems of coordination. ${ }^{39}$

Yet Perón was not preoccupied primarily with these policy experts. Rather, the Peronist government focused its efforts on convincing the Argentine public of the merits of the Plan Quinquenal and its model of state-led modernization. The regime made great pains to project an image of state planning that was at once technical and that exalted the ideals of social justice and national liberation. Indeed, the Plan presented to the public was a generalized version suited to a mass audience, complete with flowcharts and other visual aids. Peronist officials used every state, partisan, and media channel at their disposal to spread word of the Plan Quinquenal. Pro-government newspapers such as Democracia carried almost daily reports on the various issues addressed by Plan, and the federal government printed and distributed thousands of copies of the Plan for public consumption. The President himself offered a week's worth of conferences on national radio in October 1946 during which he recounted chapter-by-chapter his government's five-year objectives. He met

were administered by the Ministerio de Salud Pública and Ministerio de Obras Públicas, hundreds of individual unions, provincial agencies, and eventually the Fundación Eva Perón. The relative lack of experience of the Peronist top brass -a collection of military officers, ex-union officials, and a handful of dissident industrialists- contributed to the incompleteness of central planning in practice, and over time, Peronist authorities did take measures to impose centralization on the government.

39 Revista de Ciencias Económicas, April 1947: 261-63; January-February 1949: 29-30. González Galé (1946: 160-170). 
as well with representatives from organized labor to request their assistance in educating the rank-and-file about the Plan. An advertisement published in the Unión Ferroviaria's newspaper captures the general tone of these propaganda efforts, in particular the ways that planned progress and mass politics became intertwined under justicialista rule:

Industrializar el país, poblarlo, enriquecerlo, asegurar para todos sus habitantes condiciones de existencia decentes y normas de vida dignas, a tono con el progreso social que acusan los países más adelantados. El Plan Quinquenal ha de materializar aspiraciones tan legítimas. ¡Apóyelo! ${ }^{40}$

Visual representations were fundamental to these propaganda efforts. Posters plastered on walls across the country offered symbolic depictions of how planned government and technology were transforming the nation. One such poster used the metaphor of a cauldron of molten metal being poured into an Argentina-shaped mold to illustrate the impact of the Plan Quinquenal: industrial technology was forging a new nation. ${ }^{41}$ Pamphlets and magazines provided images of the Plan being put into action -of housing projects and hospitals under construction, gas pipelines being laid down, workers enjoying their "standard of livings", and bureaucrats hard at work in new public buildings. Statistics and charts were often included to provide social scientific evidence that would quantify how Perón and his government were delivering on their promises. ${ }^{42}$

The fundamental goal of this propaganda was to educate and even dazzle the populace with the grandeur of planning in action. At their core, these efforts were also designed to foster a sense of solidarity between state authorities and supporters at the grassroots. Indeed, propaganda-makers encouraged Argentine men and women to participate with their government in the Plan's realization. This argument may appear counter-intuitive at first glance, given the elitism generally associated with the technocracy of state planning. Yet the idea that the "pueblo" could cooperate with the president and his experts lay at the heart of the regime's attempts to convince the public that they were not mere subjects of the state, but part of a dynamic and unified partisan movement. Exactly what "cooperation" meant in this context was, to be sure, a thorny problem, and there were few institutional channels within the structures of the Peronist government for individuals to influence policymaking directly. ${ }^{43}$

$40 \quad$ El Obrero Ferroviario 1 April 1947: 3.

41 Archivo General de la Nación, Departamento de Fotografía, Caja 1307, Sobre 62, documentos 197326 and 197326.

42 See for instance, Servicio Internacional de Publicaciones Argentinas (1950) and (1952).

43 For a social historical investigation into the problem of participation, see Elena (2005). 
Especially after 1949, the regime intensified its drive to transform society into Perón's ideal of an "Organized Community," where the "masses" would be integrated within a pyramid of work, party, and social institutions with the president at the apex. Once again, Perón's militaristic ideal of an ordered nation found common ground with a conception of planning as scientific management of society. In partisan manuals such as Conducción Politica (1952), the president invoked the authority of planning in a more abstract, symbolic sense: "en la conducción política, si no tiene un plan, no se hace nunca nada racional y bien hecho." 44 Stripped of its narrow technical meanings, the "Plan" became a key metaphor within these partisan attempts to preach the mystical gospel of "conducción." By the early 1950s, the model of planning as "socioeconomic ordering" established during the war years became coupled to this idea of planning as the "Organized Community." This broadening of planning into mass politics manifested itself in stricter state control of the media, a crackdown on political dissent, and the formation of new partisan organizations (such as the Partido Peronista Femenino).

For the regime's many critics, the application of planning metaphors to political and social organization was a clear sign of Peronism's status as "fascismo criollo." Without engaging in a detailed analysis of the comparisons between Peronism and fascism, one can readily see that these political movements did indeed share a critique of liberalism, authoritarian repression of opponents, and a desire to apply the latest techniques of modern statecraft to reorder the nation. Yet there were also notable differences in how European fascist regimes and Perón's government made political use of planning, differences that anti-Peronists either did not see or chose to ignore in order to achieve their more pressing goals. In the Argentine case, for instance, state planning was part of a nationalist vision that fully embraced the idea of modernization, rather than emphasizing the need to restore lost traditions and regenerate a degraded society, as was often the case in fascist regimes. Perón's rhetoric of the "Organized Community" differed from Mussolini and Hitler's in the absence of an exaltation of a mythic past before liberalism, in which collective, organic representation held sway. ${ }^{45}$

44 Perón (1952: 240).

45 This contrast does not mean that fascists were simply critics of modernism, for they combined nostalgia for the past with an embrace of industrial capitalism. As Paxton argues, "The complex relationship between fascism and modernity cannot be resolved all at once, and with a simple yes or no. It has to be developed in the unfolding story of fascism's acquisition and exercise of power. The most satisfactory work on this matter shows how antimodernizing resentments were channeled and neutralized, step by step, in specific legislation, by more powerful pragmatic and intellectual forces working in the service of an alternate modernity". Paxton (2004: 13). 
Although these regimes often employed similar propaganda techniques in regards to the planning state, there was wide variation in the party, government, and labor institutions called upon to organize and mobilize political support.

Complementing the familiar comparison with interwar fascists, Perón can also be seen a precursor to subsequent political attempts in the postwar period to harness the power of planning in the "Third-World." As the wave of decolonization swept through Africa, Asia, and the Caribbean, national planning became increasingly divorced from its European goals of protecting pre-existing industrial capacity or limiting the effects of depression and war. Within the context of decolonization and the emergence of developmentalist ideologies, state coordination of economic activity became a means to spur industrialization and break free from traditional colonial strictures. From Nehru's India to Nasser's Egypt to Nkrumah's Ghana, national planning in the postwar world contained a crucial mass political dimension, as leaders sought to mobilize their populations behind the banner of anti-imperialism and modernization. As in Peronist Argentina, these experiments with state planning often produced narrow policymaking elites and authoritarian restrictions of the public sphere.

This mass political dimension of state planning can help explain in part a familiar paradox of Peronist rule: how a regime that concentrated policymaking authority in the executive branch was able nevertheless to generate such wide popular participation. As this essay has argued, Peronist officials invoked the authority of social science and technology in outlining their vision of postwar progress. The regime sought to convince the Argentine public to place their faith in the expertise of state officials and in the guiding force of the Conductor. In describing the concrete accomplishments of the central state, Peronist propaganda contained both these technocratic and populist dimensions. It is valid, of course, to question the supposedly "scientific" characteristics of the regime's five-year plans and the degree which social scientific experts played in actually shaping policies. (If one considers open criticism to be an integral part of the scientific method, then certainly Peronist planning fell far short of this ideal.) But it is also important to understand how technical expertise formed part of an ideology of postwar progress, constituted by a set of discourses and visual symbols, disseminated through the mass media, and articulated within government institutions.

\section{Final Remarks}

By way of conclusion, it is worth asking the question of why planning had such an appeal in wartime Argentina. The central explanation may be that this subject attracted the attention of UIA and Peronist groups for the same reason it did in 
Europe, the United States, and elsewhere in Latin America. Although Argentines were not directly involved in armed conflict, they were exposed to a similar set of risks - economic dislocation, unemployment, uncertainty-generated by the global nature of the war. Likewise, the capacious nature of postwar planning as an activity appealed to diverse groups within Argentina, each of which brought its own agenda to the conference table. "Planning" was a concept elastic enough to raise the enthusiasm of those who wished to protect business activity as well as those who sought to impose order on unjust markets. Experts and their political allies spoke the language of postwar planning in the accents of capitalist efficiency, conservative yearnings for social peace, and progressive social politics.

In Argentina, the defensive tendencies of postwar planning gave way to a much more expansive commitment to using the power of central government to transform society. Peronist planners in particular were able to tap into the concerns of reformers and labor movements, who had criticized the shortcomings of laissez-faire government and liberal economics in the 1930s. They were successful in grafting the transnational vocabulary of social politics onto popular perceptions of Argentina's inequality and injustice. Postwar planning played upon perceptions of Latin American backwardness and the need for rapid, all-encompassing change directed by the central planning state. In its Peronist variant, "governmentality" came to encompass not only management of natural resources and the capacity of the population, but also ideological consensus and control over political support. Although the regime was not entirely successful in realizing its ideal of an "Organized Community," it did nevertheless change the political landscape of Argentina. The early advocates of postwar reform might have been dismayed at how Perón's political coalition adapted policies, institutions, and discourses associated with planning to new ends. But these criticisms did not stop Perón and his followers from invoking the virtues of the "Plan," or in making state planning a centerpiece of bureaucratic power and populist politics in the New Argentina.

\section{Bibliography and References}

Adler, F. H. (1995): Italian Industrialists From Liberalism to Fascism. Cambridge: Cambridge University Press.

Archivo General de la Nación, Departamento de Fotografía, Caja 1307, Sobre 62, documentos 197326 and 197326.

Ballent, Anahí (1993): “Arquitectura y ciudad como estéticas de la política”. En: Anuario IEHS, 8 (1993), pp. 175-98.

Barkai, Avraham (1990): Nazi Economics: Ideology, Theory, and Policy. Oxford: Berg. 
Bernardo, Héctor (1945): “Intervención del estado o economía corporativa”. En: Revista de Economía Argentina, febrero, pp. 47-52.

Berrotarán, Patricia (2004): Del plan a la planificación: El estado durante la época peronista. Buenos Aires: Imago Mundi.

Berrotarán, Patricia/Villarruel, José C. (1995): “Un diagnóstico de la crisis: El Consejo Nacional de Posguerra”. En: Ansaldi, Waldo / Pucciarelli, Alfredo/Villarruel, José (eds.): Representaciones inconclusas: Las clases, los actores y los concursos de la memoria, 1912-1946. Buenos Aires: Biblos, pp. 349-383.

Birle, Peter (1997): Los empresarios y la democracia en la Argentina. Buenos Aires: Editorial Belgrano.

Brennan, James P. (1998): "Industrialists and Bolicheros: Business and the Peronist Populist Alliance, 1943-1976”. En: James P. Brennan, James (ed.): Peronism and Argentina. Willmington: S R Books, pp. 79-124.

Bunge, Alejandro E. (1940): Una nueva Argentina. Buenos Aires: Editorial Kraft.

Burchell, Graham et al. (eds.) (1991): The Foucault Effect: Studies in Governmentality. Chicago: University of Chicago Press.

Centeno, Miguel/Silva, Patricio (eds.) (1998): The Politics of Expertise in Latin America. New York: St. Martin's Press.

Consejo Nacional de Posguerra (1945): Ordenamiento económico-social. Buenos Aires.

Cramer, Gisela: (1998): "Argentine Riddle: The Pinedo Plan of 1940 and the Political Economy of the Early War Years". En: Journal of Latin American Studies 30, pp. 519-550.

Cúneo, Dardo (1967): Comportamiento y crisis de la clase empresaria Argentina. Buenos Aires: Pleamar.

De Grand, Alexander J. (2004): Fascist Italy and Nazi Germany. New York and London: Routledge.

Departamento Nacional del Trabajo (1940): La desocupación en la Argentina. Buenos Aires.

- (1942): Investigaciones sociales. Buenos Aires.

- (1943): Adaptación de los salarios a las fluctuaciones del costo de la vida. Buenos Aires.

Di Tella, Torcuato (1941): Dos temas de legislación del trabajo: Proyectos de Ley de seguro social obrero y asignaciones familiares. Buenos Aires

- (1943): Problemas de la posguerra: función económica y destino social de la industria argentina. Buenos Aires: Librería Hachette.

Di Tella, Torcuato S. (1993): Torcuato Di Tella: Industria y política. Buenos Aires: Tesis-Grupo Editorial Norma.

Dornbusch, Rudiger/Edwards, Sebastian (1991): The Macroeconomics of Populism in Latin America. Chicago: University of Chicago Press.

Elena, Eduardo (2005): "What the People Want: State Planning and Political Participation in Peronist Argentina". En: Journal of Latin American Studies 37, 1, pp. 81-108.

El Obrero Ferroviario (Buenos Aires). 
Erickson, Kenneth Paul (1977): The Brazilian Corporatist State and Working-Class Politics. Berkeley: University of California Press.

Ferguson, James (1994): The Anti-Politics Machine: Development, Depoliticization, and Bureaucratic Power in Lesotho. Minneapolis and London: University of Minnesota Press.

Figuerola, José (1939): “Organización Social”. En: Revista de Economía Argentina, Marzo, pp. 83-87.

- (1943): La colaboración social en Hispanoamérica, Buenos Aires: Editorial Sudamericana.

Gaggero, Horacio/Garro, Alicia (1996): Del trabajo a la casa: La politica de vivienda del gobierno peronista, 1946-1955. Buenos Aires: Editorial Biblos.

Gambini, Hugo (1999): Historia del Peronismo. El poder total (1943-1951). Buenos Aires: Editorial Planeta.

González Galé, José (1946): Previsión social. Buenos Aires: Losada.

Holston, James (1989): The Modernist City: An Anthropological Critique of Brasilia. Chicago: University of Chicago Press.

Knight, Alan (1998): "Populism and Neo-populism in Latin America, especially Mexico". En: Journal of Latin American Studies 30, pp. 223-248.

Llach, Juan José (1984): “El Plan Pinedo de 1940, su significado histórico y los orígenes de la economía política del peronismo". En: Desarrollo Económico 23: 92, pp. 515-557.

Little, Walter (1988): "La organización obrera y el Estado peronista”. En: Juan Carlos Torre (ed.): La formación del sindicalismo peronista. Buenos Aires: Editorial Legasa, pp. 331-376.

Lucchini, Cristina (1990): Apoyo empresarial en los origenes del peronismo. Buenos Aires: Centro Editor de América Latina.

Maier, Charles S. (1988): Recasting Bourgeois Europe: Stabilization in France, Germany, and Italy in the Decade After World War I. Princeton: Princeton University Press.

Ministerio de la Hacienda (1940): El plan de reactivación económica ante el honorable senado. Buenos Aires.

Novick, Susana (1986): IAPI: Auge y decadencia. Buenos Aires: Centro Editor de América Latina.

Page, Joseph A. (1983): Perón: A Biography. New York: Random House.

Panettieri, José (ed.) (2000): Argentina: Trabajadores entre dos guerras. Buenos Aires: Eudeba.

Paxton, Robert O. (2004): The Anatomy of Fascism. New York: Knopf.

Pereyra, Horacio José (1995): "Pinedo y El Plan Económico de 1940". En: Ansaldi, Waldo/Pucciarelli, Alfredo/Villarruel, José (eds.): Representaciones inconclusas: Las clases, los actores y los concursos de la memoria, 1912-1946. Buenos Aires: Biblos, pp. 257-258.

Perón, Juan D. (1952): Conducción Politica. Buenos Aires: Ediciones "Mundo Peronista."

- (1985): Obras completas. Vol. 7 and 8. Buenos Aires: Editorial Docencia. 
Potash, Robert A. (1969): The Army and Politics in Argentina, 1928-1945. Stanford: Stanford University Press.

Prakash, Gyan (1999): Another Reason: Science and the Imagination of Modern India. Princeton: Princeton University Press.

Presidencia de la Nación (1947): Plan Quinquenal del Presidente Perón, 1947-1951. Buenos Aires.

Pucciarelli, Alfredo (ed.) (2004): Empresarios, tecnócratas y militares: La trama corporativa de la última dictadura. Buenos Aires: Siglo XXI.

Rabinow, Paul (1989): French Modern: Norms and Forms of the Social Environment.Cambridge and London: MIT Press.

Revista de Ciencias Económicas (Buenos Aires).

Revista de Economía Argentina (Buenos Aires).

Robertson, A. F. (1984): People and the State: An Anthropology of Planned Development. Cambridge: Cambridge University Press.

Rodgers, Daniel T. (1998): Atlantic Crossings: Social Politics in a Progressive Age. Cambridge: The Belknap Press of Harvard University Press.

Ross, Peter (1993): "Justicia social: Una evaluación de los logros del peronismo clásico". En: Anuario IEHS, 8, pp. 105-124.

Rouquié, Alain (1982): Poder militar y sociedad política en la Argentina, I. Buenos Aires: Emecé.

Rueschemeyer, Dietrich/Skopol, Theda (eds.) (1996): States, Social Knowledge, and the Origins of Modern Social Policies. Princeton: Princeton, University Press.

Sarti, Roland (1971): Fascism and the Industrial Leadership in Italy, 1919-1940. Berkeley: University of California Press.

Servicio Internacional de Publicaciones Argentinas (1950): La justicia social es realizada por el pueblo. Buenos Aires.

- (1952): La asistencia social justicialista. Buenos Aires.

Schvarzer, Jorge (1991): Empresarios del pasado: La Unión Industrial Argentina. Buenos Aires: CISEA/Imago Mundi.

Scott, James C. (1998): Seeing Like A State: How Certain Schemes to Improve the Human Condition Have Failed. New Haven: Yale University Press.

Secretaría de Trabajo y Previsión (1945): Nivel de vida de la familia obrera, evolución durante la segunda guerra mundial. Buenos Aires.

- (1946 a): Condiciones de vida de la familia obrera, 1943-1945. Buenos Aires.

- (1946 b): Investigaciones sociales, 1943-1945. Buenos Aires.

Soprano, Germán (2000): "El DNT y su proyecto de regulación estatal de las relaciones Capital-Trabajo en Argentina, 1907-1943”. En: Panettieri, José (ed.): Argentina: Trabajadores entre dos guerras. Buenos Aires: Eudeba.

Suriano, Juan (ed.) (2000): La cuestión social en Argentina, 1870-1943. Buenos Aires: Editorial La Colmena.

Wynia, Gary W. (1978): Argentina in the Postwar: Politics and Economic Policymaking in a Divided Society. Albuquerque: University of New Mexico Press.

Zimmermann, Eduardo A. (1995): Los liberales reformistas: La cuestión social en la Argentina, 1890-1916. Buenos Aires: Editorial Sudamericana. 